\section{Temporal artery rupture following firework rocket injury}

Sir,

We want to report this extremely peculiar injury caused by a stray firework rocket which lead to rupture of superficial temporal artery and extradural haematoma.

Firecrackers are used around the world during various festivals, ceremonies and social events. In India, they are extensively used during Diwali also known as the 'festival of lights'. In India, firecrackers are easily available for use by the common public. Firecracker injuries usually range from various degrees of burns to blast injuries to the hand. The presentation of isolated superficial temporal artery injury following firecracker injury is an extremely rare presentation and probably the first reported in English literature.

A 17-year-old male presented to our emergency department with injury to the right temporal region following a stray firework rocket going haywire [Figure 1]. He presented with torrential bleeding due to superficial temporal artery rupture. The bleeder was clamped and ligated. A non-contrast enhanced computed tomography scan of head showed a small extra-axial bleed in the right temporal region with a hairline fracture to the right petrous temporal bone [Figure 3] and with superficial soft tissue swelling [Figure 2]. The patient was kept under observation and discharged on the $5^{\text {th }}$ day under satisfactory condition.

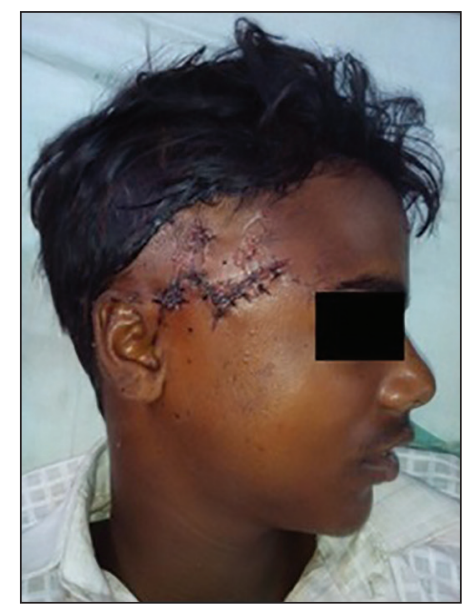

Figure 1: Sutured wound after ligation of superficial temporal artery

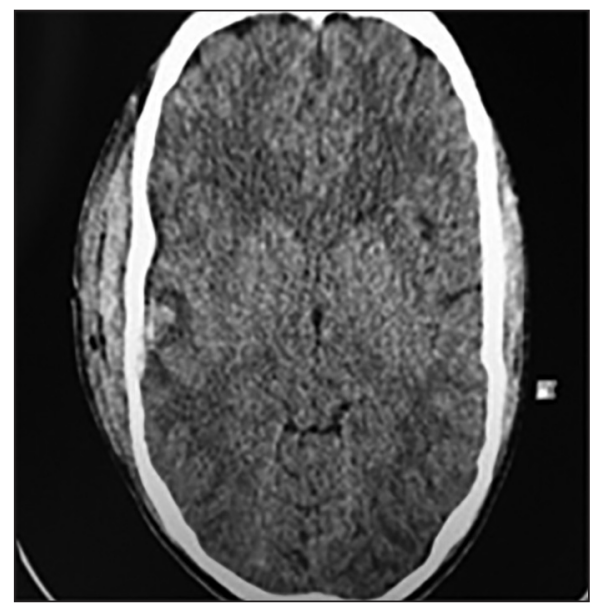

Figure 2: Small extra-axial bleed in right temporal region

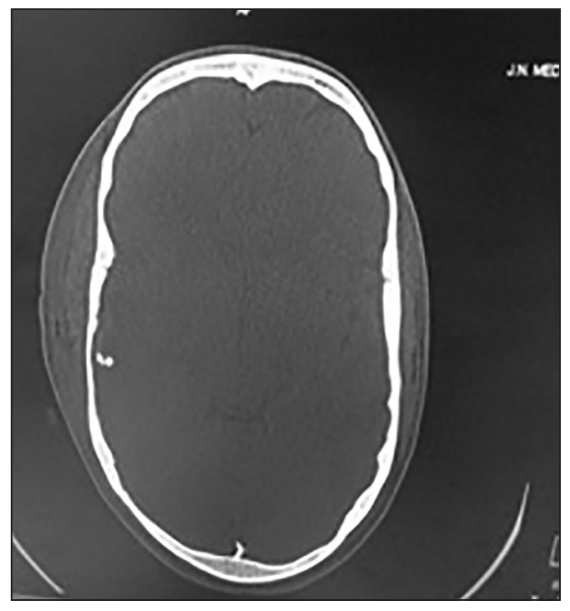

Figure 3: Hairline fracture of right petrous temporal bone

Indian Journal of Plastic Surgery May-August 2015 Vol 48 Issue 2 
The use of firecrackers is common throughout the world especially during festivities. Their use and injuries related to them reach epidemic levels in India during the celebration of Diwali. There is an obvious male preponderance, and the usual victims are between 5 and 30 years with the Anar (flower pot) being the most common causative agent, closely followed by Bombs (sound-emitting fireworks)..$^{[1,2]}$

There are conflicting reports regarding the incidence of firecracker related injuries as Tandon et al. ${ }^{[1]}$ found that the incidence is steadily increasing while Puri et al. have suggested that the incidence is decreasing. ${ }^{[2]}$ Injuries specific to the preauricular region don't usually present as a temporal artery rupture but rather the presentation is that of a temporal artery pseudoaneurysm, also called 'puck aneurysms' ${ }^{[3]}$ or 'squash ball aneurysms'. ${ }^{[4]}$ Although protected from trauma by surrounding soft tissue, the branches of superficial temporal artery lie directly on the periosteum at the superior temporal line due to a gap in the muscle and are vulnerable to trauma. The artery is also tethered by adventitia to the frontal and temporalis muscle. These anatomic peculiarities increase the likelihood of a lesion developing in case of blunt trauma. ${ }^{[5]}$ Several other injuries have been reported with stray firework rockets such as penetrating abdominal injury, ${ }^{[6]}$ penetrating sternal injury $^{[7]}$ and bony injuries. ${ }^{[8]}$

\section{CONCLUSION}

Though firecrackers usually cause burn injuries, they have a potential to cause much grievous injuries such as temporal artery rupture and extradural haematoma. Many of the firework related injuries are potentially preventable. Hence, steps should be taken by individuals, Non-Government organisations and government to prevent such injuries by awareness, public participation and legislation.

\section{Financial support and sponsorship}

Nil.

\section{Conflicts of interest}

There are no conflicts of interest.

\section{Mohd Azam Haseen, Adil Ali Mahmud, Fakhrul Huda ${ }^{1}$, Mohd Haneef Beg}

Departments of Cardiothoracic Surgery and ${ }^{1}$ Neurosurgery, Jawaharlal Nehru Medical College, Aligarh Muslim University, Aligarh, Uttar Pradesh, India

Address for correspondence: Dr. Mohd Azam Haseen, Department of Cardiothoracic Surgery, Jawaharlal Nehru Medical College, Aligarh Muslim University, Aligarh, Uttar Pradesh, India E-mail: azamjnmc@gmail.com

\section{REFERENCES}

1. Tandon R, Agrawal K, Narayan RP, Tiwari VK, Prakash V, Kumar $\mathrm{S}$, et al. Firecracker injuries during Diwali festival: The epidemiology and impact of legislation in Delhi. Indian J Plast Surg 2012;45:97-101.

2. Puri V, Mahendru S, Rana R, Deshpande M. Firework injuries: A ten-year study. J Plast Reconstr Aesthet Surg 2009;62:1103-11.

3. Campbell JS, Fournier P, Hill DP. Puck aneurysm. Can Med Assoc J 1959;81:922-4.

4. Golden GT, Fox JW, Williams GS, Edgerton MT. Traumatic aneurysm of the superficial temporal artery. Squash-ball disease. JAMA 1975;234:517-8.

5. Angevine PD, Connolly ES Jr. Pseudoaneurysms of the superficial temporal artery secondary to placement of external ventricular drainage catheters. Surg Neurol 2002;58:258-60.

6. Shakil MS, Smith JE. Penetrating abdominal wound caused by a firework. Br Med J (Clin Res Ed) 1987;295:635-6.

7. Matsumura C, Oshio T, Kawauchi M, Kirino A, Saito T, Sato Y. A rare case of penetrating sternal wound with pneumomediastinum due to fireworks (author's transl). Kyobu Geka 1981;34:59-61.

8. Garden OJ, Morris EW, Young AB. A penetrating wound of bone resulting from a firework. Injury 1983;15:167-9.

This is an open access article distributed under the terms of the Creative Commons Attribution-NonCommercial-ShareAlike 3.0 License, which allows others to remix, tweak, and build upon the work non-commercially, as long as the author is credited and the new creations are licensed under the identical terms.

For reprints contact: reprints@medknow.com

\begin{tabular}{|l|l|}
\hline \multicolumn{2}{|c|}{ Access this article online } \\
\hline Quick Response Code: & Website: \\
\hline & www.ijps.org \\
\hline & DOI: \\
\hline
\end{tabular}

How to cite this article: Haseen MA, Mahmud AA, Huda F, Beg $\mathrm{MH}$. Temporal artery rupture following firework rocket injury. Indian J Plast Surg 2015;48:225-6. 